\title{
The effects of armed conflict on forest cover changes across temporal and spatial scales in the Colombian Amazon
}

\author{
Oscar V. Bautista-Cespedes ${ }^{1,2} \cdot$ Louise Willemen $^{1} \cdot$ Augusto Castro-Nunez ${ }^{2} \cdot$ Thomas A. Groen $^{1}$ (I)
}

Received: 6 March 2020 / Accepted: 26 March 2021 / Published online: 22 June 2021

(C) The Author(s) 2021

\begin{abstract}
The Amazon rainforest covers roughly $40 \%$ of Colombia's territory and has important global ecological functions. For more than 50 years, an internal war in the country has shaped this region. Peace negotiations between the government and the Revolutionary Armed Forces of Colombia (FARC) initiated in 2012 resulted in a progressive de-escalation of violence and a complete ceasefire in 2016. This study explores the role of different deforestation drivers including armed conflict variables, in explaining deforestation for three periods between 2001 and 2015. Iterative regression analyses were carried out for two spatial extents: the entire Colombian Amazon and a subset area which was most affected by deforestation. The results show that conflict variables have positive relationships with deforestation; yet, they are not among the main variables explaining deforestation. Accessibility and biophysical variables explain more variation. Nevertheless, conflict variables show divergent influence on deforestation depending on the period and scale of analysis. Based on these results, we develop deforestation risk maps to inform the design of forest conservation efforts in the post-conflict period.
\end{abstract}

Keywords Deforestation $\cdot$ Logistic regression $\cdot$ Tropical rainforest $\cdot$ War $\cdot$ Forest conservation

\section{Introduction}

Forests play a key role in human well-being, as they provide many different types of ecosystem services (FAO 2016; DESA 2016). Deforestation reduces forest functions including carbon sequestration, biodiversity habitat and freshwater supply (Geist and Lambin 2001; Hansen et al. 2013; Van Soesbergen and Mulligan 2014). As many of the world's armed conflicts take place in tropical forests (Hanson et al. 2009; Baumann and Kuemmerle 2016; Castro-Nunez et al. 2017a), understanding the role of armed conflict on forest cover dynamics can help in reducing global deforestation.

The Amazon basin accounts for nearly half of the remaining tropical rainforest on earth (Malhi et al. 2007; Holzman

Communicated by Alta de Vos

Thomas A. Groen

t.a.groen@utwente.nl

1 Faculty of Geo-Information Science and Earth Observation, University of Twente, Po Box 21, 7500AE,

Enschede, The Netherlands

2 Alliance of Bioversity International and the International Center for Tropical Agriculture, Km 17 recta Cali-Palmira, Cali, Colombia
2008). Hansen et al. (2013) show a loss of $282.500 \mathrm{~km}^{2}$ of the Amazon rainforest between 2001 and 2013, an area almost the size of Italy. Deforestation is associated with specific temporal and spatial characteristics (Geist and Lambin 2001), of which population density, economic development and agricultural activity have been identified as common drivers of recent deforestation in tropical countries (Leblois et al. 2017). In the Amazon region, deforestation is predominantly linked to infrastructure development (including road construction), cattle ranching, industrial agricultural expansion, mining, logging and land speculation (Laurance et al. 2002; Malhi et al. 2007; Santé et al. 2010; Rosa et al. 2013; Van Soesbergen and Mulligan 2014; Barber et al. 2014; Miranda et al. 2019).

The Colombian share of the Amazon accounts for nearly $10 \%$ of its total area. Annual deforestation rates range from to 0.38 to $0.77 \%$ in the most affected provinces, and these are significantly higher than those found in other Amazon countries such as Brazil, Peru and Ecuador (Armenteras et al. 2006; Murad and Pearse 2018). Deforestation has surged since 2016 a record of nearly 215,000 ha were deforested in the Colombian Amazon during 2018 (Hettler et al. 2018; MAAP 2019; Finer and Mamani 2020). Documented deforestation drivers in the Colombian Amazon include illicit crop cultivation, agriculture expansion, extensive cattle ranching, 
infrastructure development and wood extraction. Meanwhile, reported underlying drivers of deforestation include inadequate government policies, poverty, armed conflict, forced displacements and land grabbing (Armenteras et al. 2006, 2013a, 2019; Etter et al. 2006b; Sánchez-Cuervo and Aide 2013a; Castro-Nunez et al. 2017a; Murad and Pearse 2018; Hoffmann et al. 2018; Landholm et al. 2019; Negret et al. 2019; Furumo and Lambin 2020).

In Colombia, the long-lasting armed conflict has brought about 35,000 armed actions, caused the disappearance of more than 80,000 people, and more than 260,000 fatalities since 1958 (Centro Nacional de Memoria Histórica y Observatorio de Memoria y Conflicto 2018). In the Amazon, the departments most affected by the conflict have been Meta, Caquetá, Putumayo and Guaviare, with roughly 5000 armed confrontations between 1954 and 2018 (Álvarez 2003; Castro-Nunez et al. 2017b; Landholm et al. 2019). Earlier work has shown that the long-lasting armed conflict has influenced forest cover dynamics in various ways. For instance, violent confrontations between armed groups and government forces that caused population displacements resulted in forest regrowth in some areas and deforestation in others (Sánchez-Cuervo et al. 2012; Castro-Nunez et al. 2017a). Establishment of illegal crops usually causes forest clearance, while abandonment of areas due to the existence of antipersonnel landmines facilitates forest regeneration (Ibañez and Vélez 2007; Fergusson et al. 2014; Baumann and Kuemmerle 2016; Morales 2017).

Previous studies on the relationships between armed conflict and deforestation in Colombia report divergent results. Of these, earlier studies usually focused on social, demographic and environmental aspects; meanwhile, more recent research has had incremental interest in elucidating the role of armed conflict on biodiversity hotspots. For instance, Armenteras et al. (2006, 2013a) explored deforestation drivers by looking at violent episodes and illicit crops and did not find any relationship between these two conflict variables and deforestation. Etter et al. (2006a) found that guerrilla activities increase deforestation, yet armed conflict was not included as an explanatory variable in their study. Dávalos et al. (2011) found that deforestation was influenced indirectly by coca (Erythroxylum coca) trafficking. Here, deforestation was driven through the production of other crops using income generated from coca cultivation, but also by coca eradication efforts, which would force farmers to relocate and deforest new areas. SánchezCuervo et al. (2012) suggested that forest recovery was largely driven by land abandonment associated with the intensification of the armed conflict nationally; yet, when looking at moist forest regions such as the Amazon, deforestation remains higher than recovery rates. Castro-Nunez et al. (2017a) argue that large-scale forest cover changes typically take place in areas with high-value natural resources and operation of illegal groups and, especially where people have been victim of violence and forced displacement, and/or where there is competition for the control of scarce resources such as land. Their findings suggest links between deforestation and unequal land distribution, land grabbing, illicit crop production and forced migration. In the same way, Hoffmann et al. (2018) indicate that deforestation is caused by the uncontrolled colonization of land, forced displacement waves and the eradication of illicit crops. Additionally, CastroNunez et al. (2017b) highlight the importance of the study scale as biophysical, socio-economic, political and demographic diversity is observed across Colombia.

More recently, Negret et al. (2019) investigated the relationships between deforestation and armed conflict, coca plantations, mining and oil concessions at the national level. Their results suggest that armed conflict and coca cultivation had a clear effect on deforestation when considered individually, but these effects were attenuated when combined with other variables. Their results also show the necessity of using a more spatially explicit conflict datasets especially in areas with extensive municipalities such as the Amazon. Landholm et al. (2019) studied the armed conflict-forest dynamics, including deforestation and forest recovery, at the municipality and department level in Colombia. The study included the direct impact of armed conflict on land use change using georeferenced conflict events. Their findings suggest that internally displaced people show different conflict intensities at subnational scales. However, relationships between the armed conflict and deforestation are not entirely clear.

All these studies contribute to our improved understanding of the forest-conflict relationship in Colombia. Nevertheless, they are not conclusive about how the effects of armed conflict variables on deforestation vary over time, particularly in the Colombian Amazon. This study contributes to fill this research gap, by exploring how spatial and temporal changes in conflict variables shape their influence on deforestation. First, we elucidate the importance of deforestation drivers at different time steps and spatial extents. Second, we investigate the direct impact of armed conflict on deforestation using georeferenced armed conflict data and distance to conflict events as a proxy. Third, we analyse the variation in relationships between deforestation and its drivers at different periods and scales of analysis. Finally, using statistical modelling, we build spatially explicit deforestation models for each period and spatial extent analysed. Through this, we aim to improve the understanding of spatial and temporal relationships between deforestation and armed conflict, as well as the potential impacts of the post-conflict for the conservation of forests in the Colombian Amazon.

\section{Data and methods}

\section{Study area}

The Amazon region encompasses around $40 \%$ of Colombia's territory and comprises eight administrative departments: 
Putumayo, Caquetá, Amazonas, Meta, Guainía, Guaviare, Vaupés and Vichada (Fig. 1). This region is mainly covered by tropical forests, but also contains wetlands, dry savannahs and montane forests (Eden 1990; Sánchez-Cuervo et al. 2012). The annual precipitation of the area ranges between 1000 and $5000 \mathrm{~mm}$. High levels of precipitation are observed in the Andes foothills as well as in the eastern part of the country, while the central section of the Colombian Amazon receives relatively low (2000-3000 $\mathrm{mm}$ ) rainfall amounts per year (Fick and Hijmans 2017).

Agricultural production and cattle ranching are the main economic activities of the area, being the predominant sectors in the departments of Caquetá and Guaviare. Furthermore, oil and gold extraction take place in some areas of the Putumayo and Caquetá department; however, these activities are marginal in the study area (Idrobo et al. 2014; Alvarez-Berríos and Mitchell Aide 2015; SIAC 2020; Bonilla Mejía 2020). Most of the human population is settled in the north west of the region, of which 50\% lives in a rural setting and 50\% in an urban setting (Arcila 2010; Dávalos et al. 2014). Department capitals such as Florencia in Caquetá and San José del Guaviare have witnessed accelerated population growth.
Some areas of the Amazon region have been controlled by different armed groups over the decades. Consequently, violence associated with drug trafficking and armed conflict has been a constant factor in the region (Armenteras et al. 2006, 2013a; Etter et al. 2006b; Arcila 2010).

To detect different outcomes that may be influenced by area of analysis, such as clustered armed conflict events or distribution of land ownership, two study areas were considered for the analysis (Fig. 1). The first one represents the Colombian Amazon as delineated by The Amazon GeoReferenced Socio-Environmental Information Network, which includes the Amazon basin and areas that are biophysically and culturally linked to the basin (RAISG 2012). The second area is a subset of the first area, hereafter referred to as the "frontier zone". This is an area characterised by recent human colonization, continuous expansion of agricultural areas and a deforestation hotspot in the Colombian Amazon region (Etter et al. 2006a; Armenteras et al. 2013b). The delineation of the frontier zone was achieved in three steps. First, we selected the department capitals of the areas where observations of deforestation from the Global Forest Change dataset (Hansen et al. 2013) were concentrated.

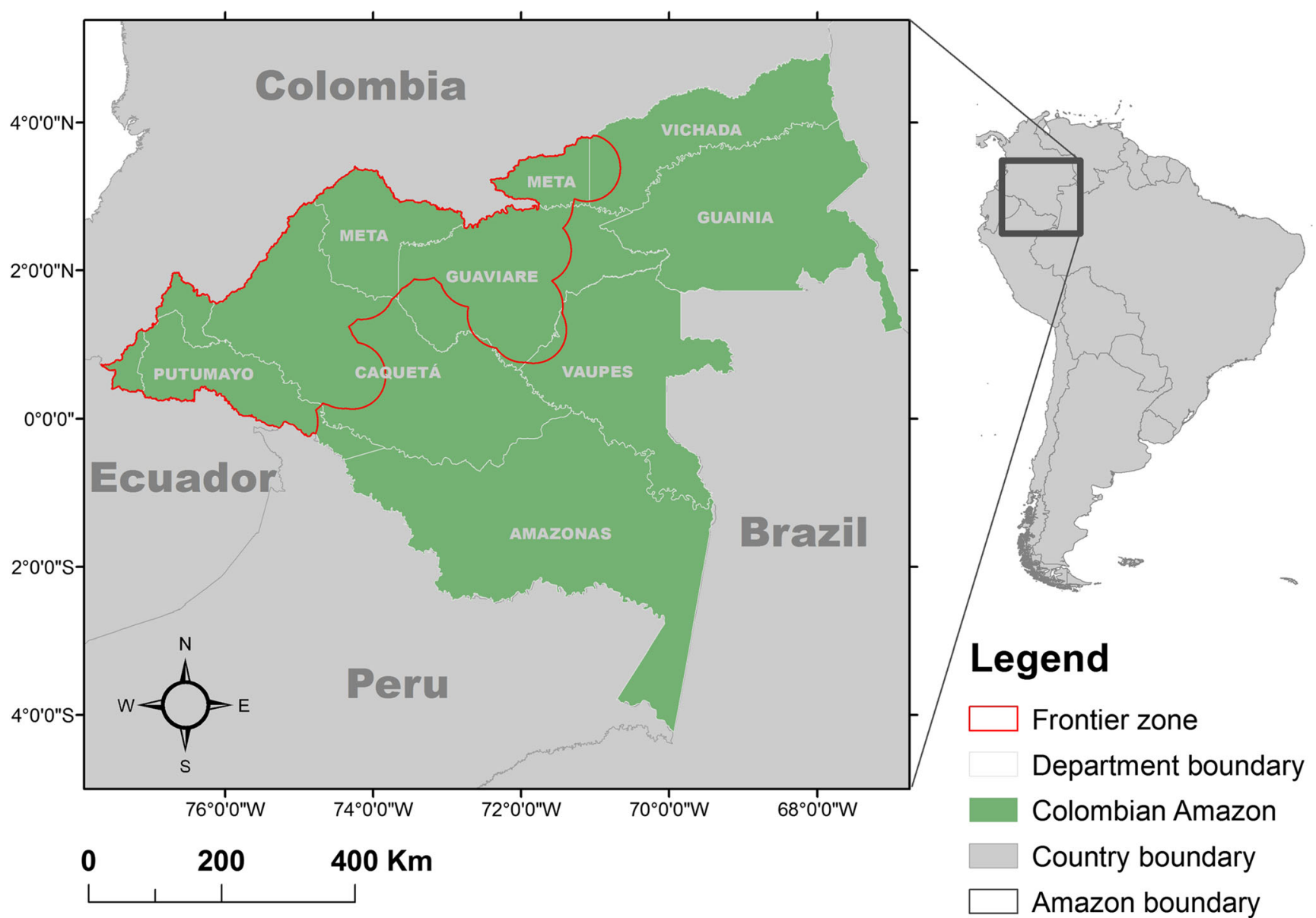

Fig. 1 Study area including Amazon and frontier zone boundaries, the frontier zone is the area of the Colombian Amazon where most deforestation is observed, it was defined based on observations of deforestation and proximity to human settlements 


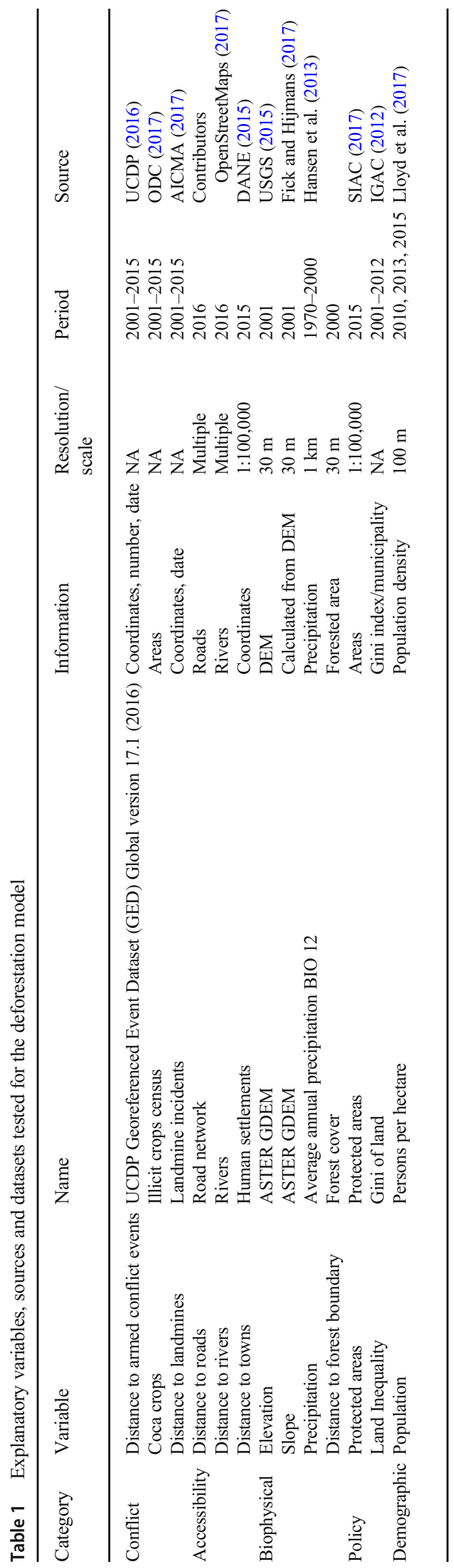

Second, we selected urban settlements located within $200 \mathrm{~km}$ from these capitals. Third, we delineated a buffer of $50 \mathrm{~km}$ around the selected settlements. The buffer distances were selected based on the observed deforestation data with the premise that deforestation usually takes place in proximity to markets and roads (Geist and Lambin 2001; Armenteras et al. 2011; Salonen et al. 2014; Müller et al. 2016). By considering these two levels, we aim to identify whether variables associated with deforestation change when studying areas with different deforestation patterns.

\section{Data and sampling}

Deforestation data were obtained from the Global Forest Change (GFC) version 1.3 (Hansen et al. 2013). This dataset offers information on forest loss on an annual basis at approximately $30-\mathrm{m}$ spatial resolution at the Equator, covering the period 2001-2015. It provides data on forest change at the global level with accuracies above $80 \%$. The dataset is derived from Landsat 7 Enhanced Thematic Mapper Plus (ETM+) imagery; the classification of the imagery was implemented using images taken in the growing season, defining forest loss as the replacement of forest to other land covers. To explain deforestation, we based our selection of variables on previous studies analysing deforestation in Colombia, with particular focus on the Amazon region (Armenteras et al. 2006, 2013a; Etter et al. 2006a, b; Dávalos et al. 2011; González et al. 2011; Sánchez-Cuervo et al. 2012; Sánchez-Cuervo and Aide 2013a, b; Chadid et al. 2015; Castro-Nunez et al. 2017a). The 13 selected variables can be categorised in five main groups: (1) conflict, (2) accessibility, (3) biophysical, (4) policy and (5) demography variables (Table 1). Maps of these 13 variables and their description are presented in the supplementary materials (Figure S1 and Table S1). Although some of the variables used in this study are at global scale, these are sometimes the only consistent and updated source of data, particularly in developing countries, where population, deforestation, climatic or conflict data are not existent or not frequently updated at country level.

Some additional steps were taken to create the final set of spatial variables to analyse deforestation. Variables for the 'conflict' category were selected after an exploratory data analysis. The initial variables included were armed conflictrelated events, antipersonnel landmines, density of coca crops per municipality and forced displacement. A Pearson correlation test showed low correlation between forced displacements and deforestation rates at municipal level $(r=0.54$ for expelled people and $r=0.03$ for incoming people) and was therefore excluded from further analyses (Figure S2). Land inequality is one of the policy variables. For this variable, the Gini coefficient of land ownership (IGAC 2012) was rasterised at municipality level, where all missing data were 
assumed to be state-owned land as it is consistent with remote areas of natural rainforest (Table S2). Forest boundary was included as one of the biophysical variables; it was computed as the perimeter of remaining forest patches in the year 2000 from the GFC dataset (Hansen et al. 2013).

To ensure a consistent spatial resolution, the response and all the variables were rasterised and resampled to $1 \mathrm{~km}$ cell size, which is the spatial resolution of the lowest dataset used (in this case, the climatic data). Data on forest cover were resampled to $1 \mathrm{~km}$ using a majority filter. Hence, each class (forest, non-forest and deforested) was extracted as a binary map. Elevation and slope were resampled to $1 \mathrm{~km}$ by capturing the mean of all the $30 \mathrm{~m}$ pixels inside each $1 \mathrm{~km}$ pixel. Population data were averaged (2010, 2013, 2015), and subsequently resampled to $1 \mathrm{~km}$ adding all the values of $100 \mathrm{~m}$ pixels inside each $1 \mathrm{~km}$ pixel.

To analyse possible changes in deforestation drivers over time, datasets with annual data availability such as deforestation, armed conflict-related events, coca crop density and antipersonnel landmines, were separated in three periods of 5 years each. These follow a failed peace process between the Colombian government and the FARC ended in 2002, which included a demilitarised zone (“Zona de distención”). Thus, we used data from 2001 to 2005 (period 1), a period with fluctuating deforestation, fluctuating conflict events with similar trends and decline in coca areas. This period also corresponds with a government transition (2002) and the increase of military actions because of policies oriented to gain control of the conflict areas by military means and aerial coca fumigation using glyphosate. In 2006-2010 (period 2), a reduction in conflicts and hectares of coca planted occurred, corresponding with post-paramilitary group demobilization (2006) and continuous airborne coca fumigation. Lastly, 2011-2015 (period 3) is characterised by reduced armed conflict, a surge of coca-planted areas, that matches the initiation of the peace negotiations with FARC in 2012 (Fig. 2).

With the selection of these periods, we aimed to (1) have a comparable number of years in each period, (2) have sufficient years in each period that maximises the chances to identify differences across time and (3) minimise biases caused by a 'subjective' selection of periods. For instance, an alternative selection of periods of analysis could be based on government administrations or based on attempts to negotiate peace with the FARC, paramilitary groups and other illegal armed forces. Based on such criteria, the following periods would be selected: (1) 1998 and 2002, when the administration of then President Andres Pastrana established a demilitarised zone where negotiations with the FARC were held. (2) 2003-2008 when the administration of then President Alvaro Uribe negotiated a peace agreement with the United Self-Defences of Colombia. However, as deforestation and armed conflicts are influenced by multiple factors, selecting periods based on a single specific criterion could result in the exclusion of available observations or jeopardise the changes in roles of the studied variables (Figure S3). To avoid this, we opted for an impartial and transparent time split rather than a preconceived period definition that can vary depending on perspective.

As we aimed to build a logistic regression model to quantify deforestation probabilities, deforested and non-deforested observations were needed for each of the three periods for both study area extents. To reduce spatial autocorrelation (i.e. have independent observations in our regression model),

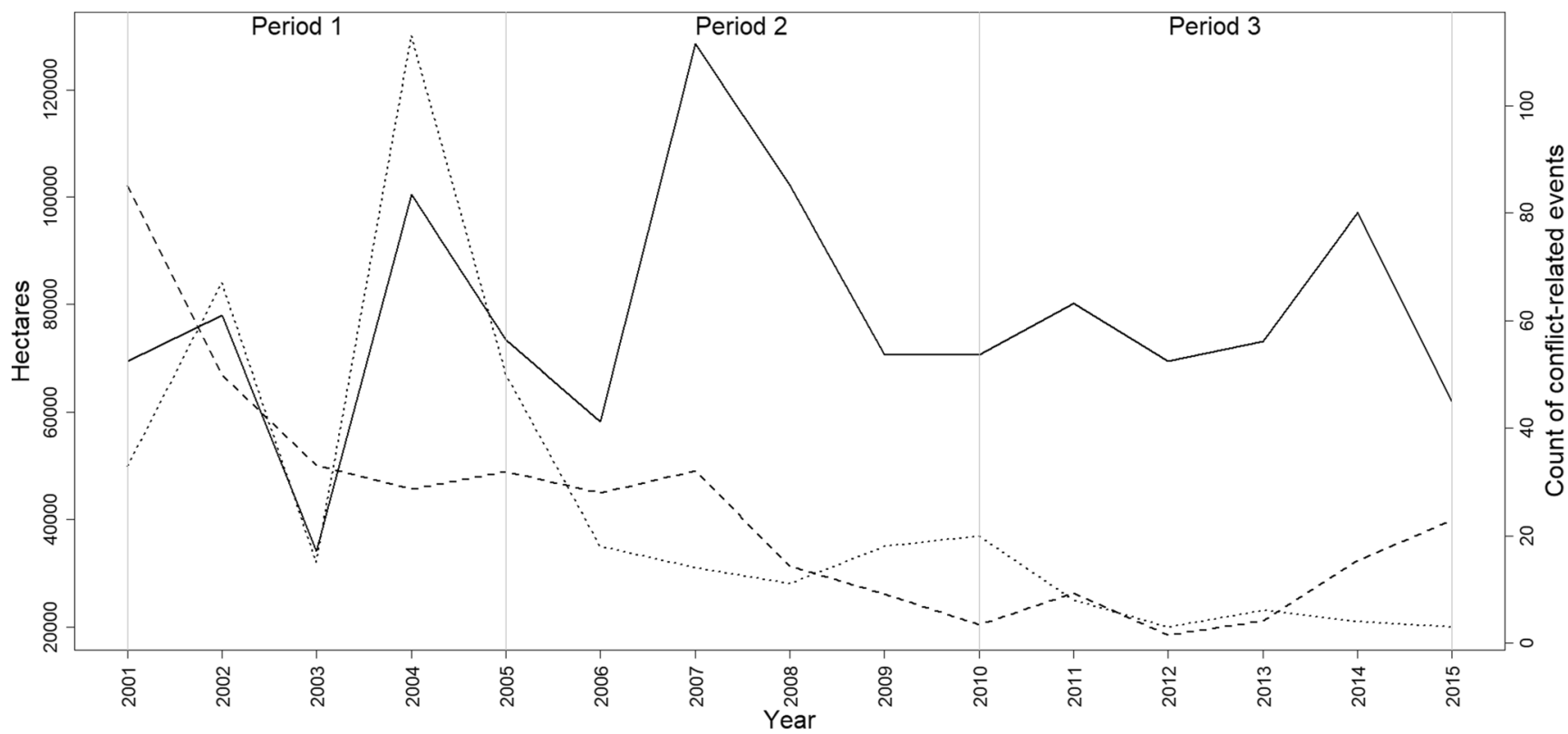

Fig. 2 Colombian Amazon timeline of Global Forest Change (GFC) data of deforestation (solid line), armed conflict-related events from the Uppsala Conflict Data Program (UCDP; dotted line), and area planted with coca from the United Nations Office on Drugs and Crime (ODC-UNODC) data (dashed line). Vertical grey lines indicate the periods of analysis of this study 
we sampled 50\% non-deforested and 50\% deforested pixels. Consequently, the sample sizes $(n)$ were two times the number of deforested pixels in the corresponding area and period. We used purposive sampling to select deforestation pixels, but random sampling to select non-deforested pixels. Thus, for the Amazon models, in total, $n=6000,7510$ and 6426 observations for the periods 1,2 and 3, respectively. While for the frontier zone models, the sample sizes were $n=5252,6864$ and 5462 for periods 1,2 and 3, respectively.

\section{Explanatory models for deforestation}

Multicollinearity refers to the correlation between explanatory variables. It hampers the effective estimation of relationships between the response and the explanatory variables used in regression models. High multicollinearity often leads to high variances and low statistical significance (Farrar and Glauber 1967; Jou et al. 2014; Zuur et al. 2010). We used the variance inflation factor (VIF) as indicator of correlation between explanatory variables, and we set an upper threshold of 4 as acceptable VIF value (Table S3).

We fitted 100 models using backward and forward stepwise logistic regressions (binominal generalised linear models), coupled with subsampling procedures (Efron 1979). Thus, for each iteration, a subsample was randomly selected followed by the stepwise regression. This operation was performed for every study extent and period (Tables S4 S9), using the Raster (Hijmans 2016) and rgdal (Bivand 2017) packages in R (Script S1). The subsampling procedures consisted of a random selection within the sample, which resulted in a test and a training dataset including 70\% and 30\% of the samples, respectively, for each period and study extent. Hence, the test datasets are different but comparable to the datasets used to train the models and can be used to evaluate model performance. We fitted generalised linear models since previous studies have shown that they have the advantage of being more generalizable compared to machine learning algorithms as they have a smaller chance of being overfitted (Duque-Lazo et al. 2016; Rocha et al. 2017).

To evaluate the importance of each variable in explaining deforestation, we recorded for each generated subsample: (a) the number of times that a variable was included in the regression models; (b) the number of times that a variable was included but was not significant; (c) number of times that a variable was significant with $p<0.05$; and (d) the number of times that a variable was significant with $p<0.01$. In addition, we scored whether relationships were found to be positive or negatively correlated to deforestation and evaluated variations in these relationships among the different time periods and study extents. We also propose a threshold of $50 \%$ of a variable being included in the stepwise regression models, which determines whether the variable should be considered for the model or discarded.
Deforestation probabilities were calculated from the average of all stepwise regressions resulting from the subsampling procedures. As a result, a map of the average deforestation probability was produced for each study area and period. To test the robustness of the predictions in relation with the sample selection, standard deviations of the deforestation risk maps were computed for each case and averaged to determine the robustness of the risk maps.

The performance of each model was tested through receiver operating characteristic curve (ROC), calculating the area under the curve (AUC) using the PresenceAbsence package in R (Freeman and Moisen 2008). A perfect prediction would be an AUC of 1, a poor outcome is closer to 0.5 (Bradley 1997; Fawcett 2005). These results were compiled in boxplots showing the variability inside modelled periods and spatial extents.

\section{Results}

\section{Drivers of deforestation in the Colombian Amazon}

The stepwise regressions for the Amazon-wide models suggest that elevation, distance to towns, distance to forest boundary and distance to roads were consistently and significantly associated with deforestation in all periods studied (Fig. 3). For the conflict variables, distance to armed conflict-related events was significant only after 2006, while distance to landmines was significantly associated with deforestation only until 2005. On the other hand, coca crop density was not significantly related to deforestation in any period. Additionally, when conflict variables were significant, these showed a positive association with deforestation. Armed conflict-related events and landmines were quantified as distances to their location. Thus, the negative beta coefficient (Fig. 3) indicates deforestation increase with proximity to conflict-related variables.

For non-conflict variables, elevation was significant at $p<$ 0.01 suggesting more deforestation in lowlands than in highlands. In the same way, distance to human settlements was significant at $p<0.01$. This suggests high deforestation in proximity to towns. The proposed threshold for variable significance shows that for $p<0.01$, between five and six variables were included, while when the threshold was softened to $p<0.05$, one more variable could be added.

In terms of relationships, most of the variables show negative relationships with deforestation, except for slope in most cases (Fig. 3 a, b, c, d and f), and inequality in land distribution in all cases. A positive relationship with slope was not expected, as usually steep slopes present adverse conditions for deforestation. However, the slope variable was not found significant in any of the cases. The positive relationship between 


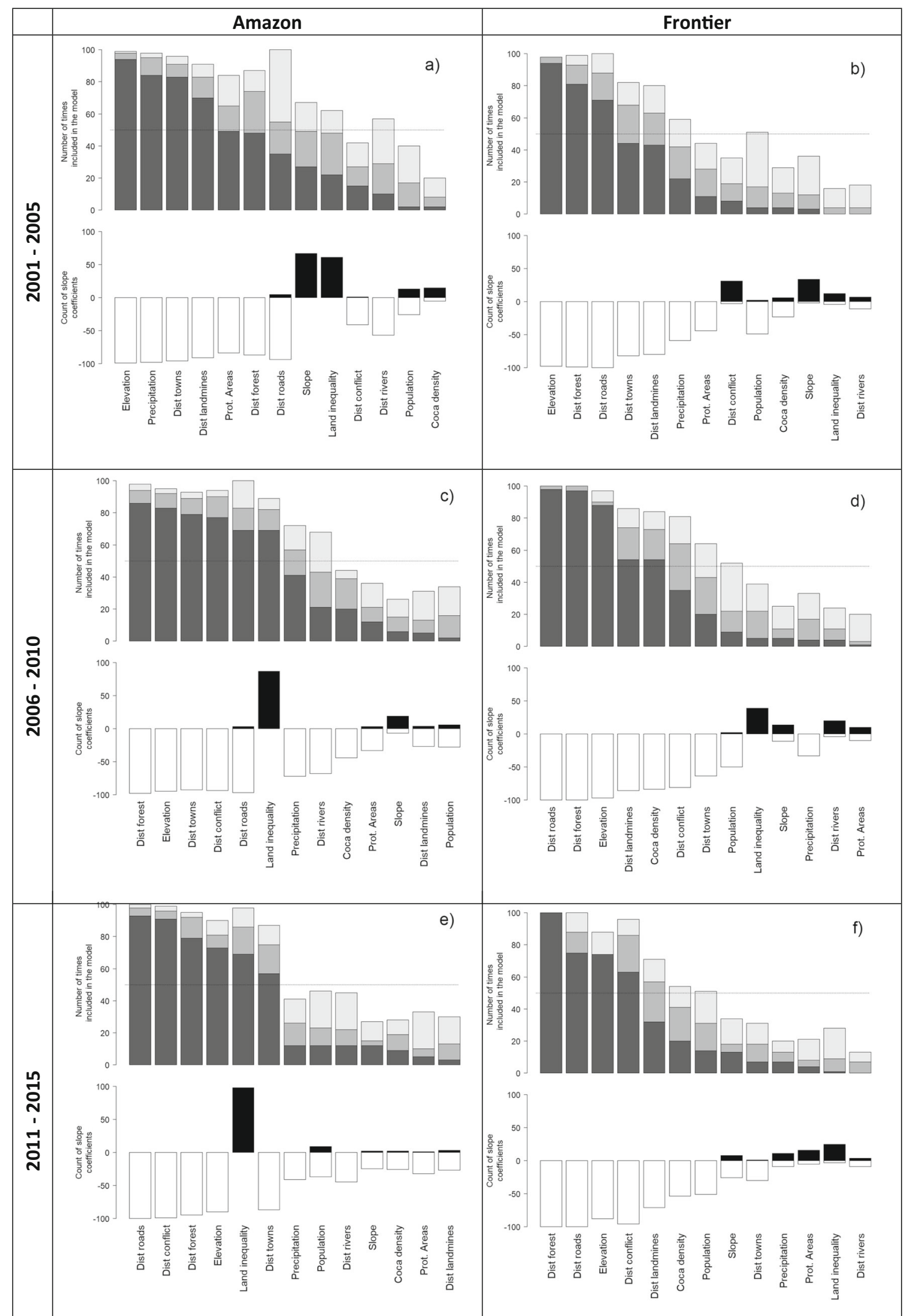

Fig. 3 Number of times a variable was retained in a stepwise model during the replication routine, Amazon (left), frontier zone (right). The top bars show level of significance: $p>0.05$ (light grey), $p>0.01$ and $p \leq$ 0.05 (medium grey) and $p \leq 0.01$ (dark grey). The bottom bar counts whether the sign of the relationship was positive (black) or negative (white). The dashed line indicates the 50\% threshold used to filter covariates. The lower plot shows the count of signs of the slope coefficients for each variable 
inequality in land ownership suggests that deforestation increases at higher inequality in land ownership.

\section{Drivers of deforestation in the frontier zone}

The stepwise regressions for the frontier zone models show that elevation, distance to forest boundary and distance to roads were significant for all the periods. From the conflictrelated variables, distance to landmines was repeatedly included in all periods and was significant. Distance to armed conflict-related events was significant in the periods 2006 to 2010 (Fig. 3d) and 2011 to 2015 (Fig. 3f), but not between 2001 and 2005 (Fig. 3b). Coca crop density was significant only in the period 2006 to 2010 .

Relationships for all significant conflict variables were negative, concurring with the results for the Amazon models, with exception of inequality in land ownership. Significant non-conflict variables such as elevation, distance to forest boundary, distance to roads and distance to towns showed negative relationships, as in the case of the Colombian Amazon area. At $p<0.01$ and $p<0.05$, three to four and five to six variables, respectively, should be included in the model after applying the 50\% threshold selection proposed (Fig. 3).

\section{Overall model results}

The performance of the models, expressed as AUC, shows comparable values between time periods (Figure S4 and Table S10). It also shows average performances higher than 0.8 for the Amazon models and 0.7 for the frontier zone models.

Deforestation risks are high in proximity to deforested areas. The areas under risk have increased in some areas of the north, north west, central, south and east of the Amazon for the period 2001-2010 period, while in the period 20052015 , the risk increased in the central areas, south and south east (Fig. 4). The frontier zone shows most risk increases in the central and western areas for the period 2001-2010, whereas in the period 2006-2015, risk increases mostly occurred in the southern areas. The standard deviation maps (Figure S5) show the areas where uncertainty was high. In some specific spots, the deforestation risk may diverge up to 0.5 , and the results of these areas need to be interpreted with caution. a)
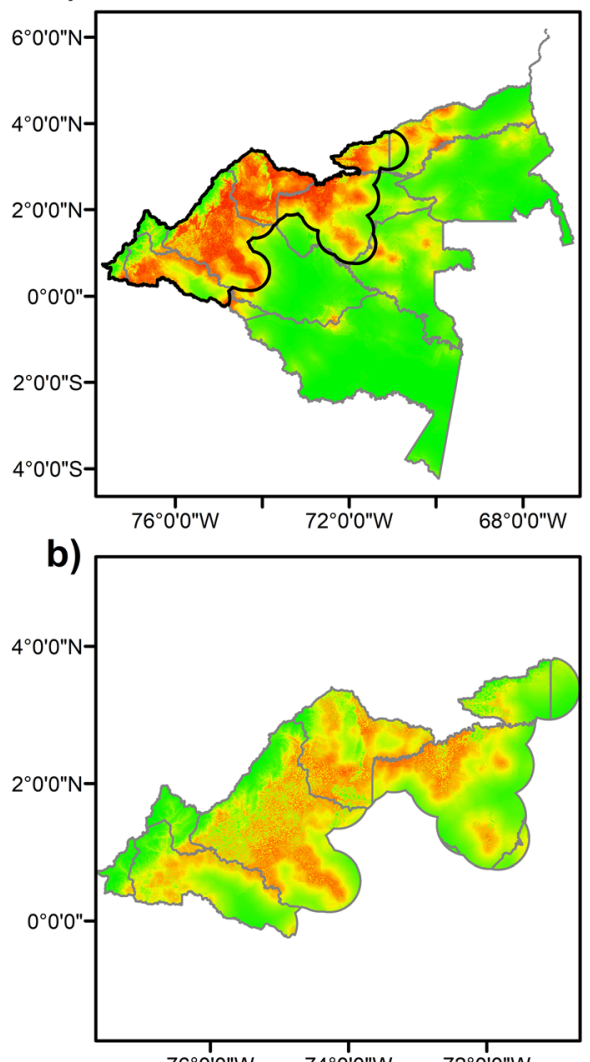

$76^{\circ} 0^{\prime} \mathrm{O}^{\prime \prime W} \quad 74^{\circ} \mathrm{O}^{\prime} \mathrm{O} \mathrm{W} \mathrm{W} \quad 72^{\circ} \mathrm{O}^{\prime} \mathrm{O} \mathrm{W} \mathrm{W}$
2006-2010
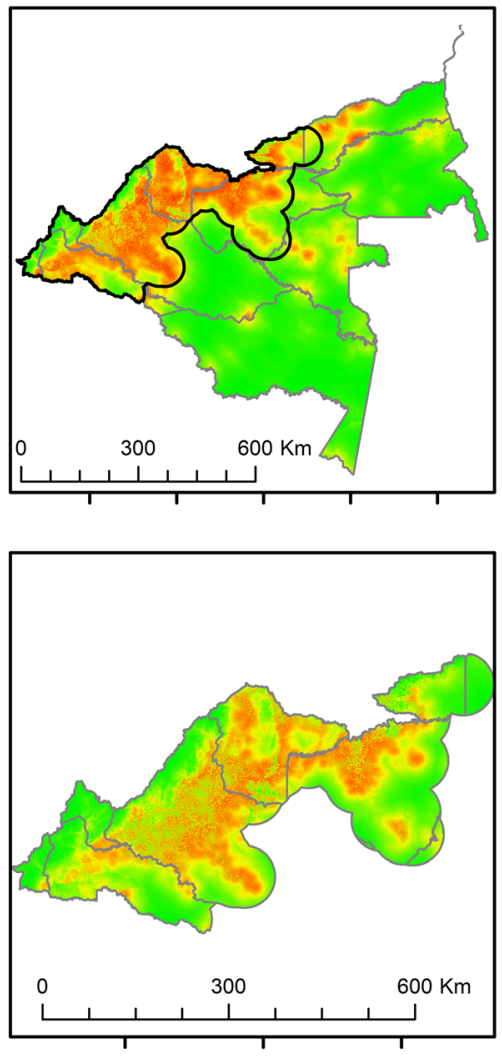

2011-2015

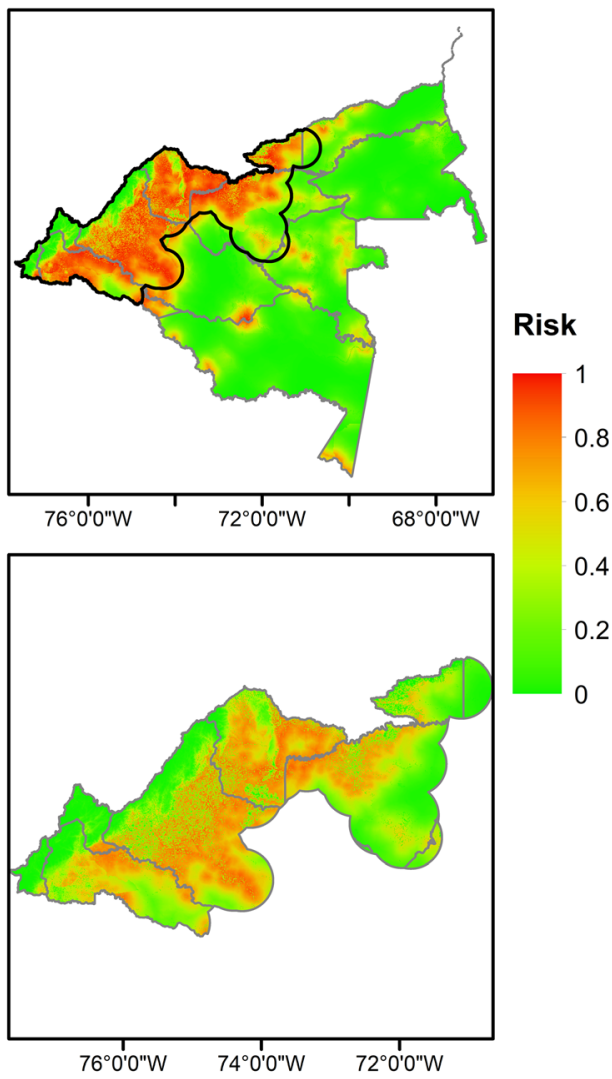

\section{$\square$ Frontier Zone boundary $\square$ Department boundary}

Fig. 4 Deforestation risk maps for $\mathbf{a}$ Amazon models and $\mathbf{b}$ frontier zone models 


\section{Discussion}

In this study, we analysed different drivers of deforestation in the Colombian Amazon, including variables associated with the armed conflict. Furthermore, we examined the variation of significance of deforestation drivers, in three different periods, and at two scales. Our results show variations in the significance, importance and sign of the relationships of the explanatory variables over time, as well as differences associated with the extent of the study area. The importance of conflictrelated variables is more dynamic over time when compared with biophysical, demographic and biophysical variables. At the same time, these changing roles of conflict variables over time are easier to identify in areas as the frontier zone rather than on large regions such as the Colombian Amazon.

\section{Changing roles of armed conflict on deforestation}

Our analyses showed that areas in proximity to armed conflict events presented more deforestation in the period 2006-2015 in both study extents. This refutes the findings of Landholm et al. (2019), according to which there was no relationship between land use and armed conflict variables in the period 1992-2015. However, our findings strengthen previous studies that report differentiated spatial and temporal roles of conflict in deforestation in Colombia (Castro-Nunez et al. 2017b). More specifically, our results show that these relationships exist and change over time; therefore, they need to be studied at different time steps.

The increase of deforestation in areas with less conflict has been reported previously (Baptiste et al. 2017; Negret et al. 2017, 2019; Landholm et al. 2019). Our results also suggest an increase of deforestation risk (Fig. 4); this might be associated with the reduction of the armed conflict-related events, from 2006 to 2015 when the number of armed conflict-related events declined in the area, deforestation increased but also did the areas planted with coca (Fig. 2). The FARC have been operating intensively in the Colombian Amazon until 2012, during the period 2002-2008 (during "plan Colombia"), government forces intensified their military actions and progressively gained more control over areas previously occupied by insurgent groups. This resulted in an increasing pressure over forest resources due to the increased accessibility to areas off limits when the conflict was more intense. More recently after the peace process and following the withdrawal of the FARC from the field, the deforested areas have increased rapidly (Hettler et al. 2018; IDEAM 2018; MAAP 2019); this suggests the end of the gunpoint forest conservation attributed to FARC (Murillo-Sandoval et al. 2020). Opposite to our results, Sánchez-Cuervo and Aide (2013a) had not found conflict as a relevant deforestation factor for the Amazon biome. Aside from differences in the conflict data granularity, this is likely linked to the changing role of conflict over time. Our results show that conflict-related variables start being more relevant after 2005.

Although different studies have included forced displacement as an important deforestation driver (Ruiz et al. 2013; Sánchez-Cuervo and Aide 2013a; Castro-Nunez et al. 2017a), our initial exploratory analyses revealed large variation in forced displacement numbers across regions, with the Amazon being a relatively low migration region when compared with other regions of the country; furthermore, forced displacement data showed low correlation with deforestation rates at municipality level (Figure S2). This corresponds with results from Sánchez-Cuervo and Aide (2013b) that did not find relationships between forced displacement and deforestation in the Amazon.

The relationship between deforestation and landmines was significant in all periods at the frontier zone level, but only between 2001 and 2005 at the Amazon level (Fig. 3a). These results suggest that the effect of landmines on deforestation should be studied at the local level in this area, as distribution of landmines in this region is clustered in specific areas. In the same way, results show that areas in proximity to landmines present more deforestation, which refutes the premise that mined fields and surrounding areas are usually not transformed by local communities, and therefore not deforested (Baumann and Kuemmerle 2016; Schultz et al. 2016; Makki et al. 2017). As a result of the armed conflict and the illegal coca production, Colombia is one of the countries most affected by the use of landmines (Cardona et al. 2014). However, few studies have investigated the effects of landmines on forest resource conservation in the country. In the case of Colombia, landmines are usually installed to prevent access to coca plantations or to restrict access of military forces to strategic areas for insurgent groups (Cardona et al. 2014). In that sense, we hypothesise that coca plantations and associated illegal practices would be causing deforestation in those areas rather than the landmines; however, more evidence is needed to understand this result.

Production of coca has provided financial resources to support the armed conflict in Colombia (Álvarez 2003; Ibañez and Vélez 2007; Dávalos et al. 2011; UNODC 2017). Our results show that coca density is only significant in the period 2006-2010 for the frontier zone model (Fig. 3d). Coca plantations have been documented by local actors and recent research as an important driver of deforestation (Dávalos et al. 2011; Hoffmann et al. 2018; Negret et al. 2019). Nonetheless, our model does not capture a consistent relationship between these phenomena in all periods. We argue that areas used to plant coca are insignificant when compared with the total deforested area. Hence, the spatially aggregated data used in this study might not be adequate to accurately evaluate the influence of coca plantations on deforestation. Nevertheless, previous studies have showed no clear relationships between 
coca and deforestation either (Sánchez-Cuervo and Aide 2013b; Armenteras et al. 2013a; Dávalos et al. 2016). It is likely that a forested area previously cleared to establish a coca plantation becomes a hotspot for expansion of agricultural areas and pastures with the time (Dávalos et al. 2011; Armenteras et al. 2013a; Chadid et al. 2015; Castro-Nunez et al. 2017a). The changing relevance of coca shown in our analysis might also be associated with relocation of coca crops resulting from government's eradication changing strategy, a situation that has been discussed in previous research (Dávalos et al. 2011; Rincón-Ruiz et al. 2013; MurilloSandoval et al. 2020).

Differences in the role of conflict variables over time might be related to different strategies adopted by armed groups to maintain or gain territorial control, we provide some possible causes leading to changes in relevance of conflict and nonconflict variables for each period studied (Table 2). These hypotheses are based on how armed groups use the forests (hideout, resource or battlefield) as described by CastroNunez et al. (2017b). On the other hand, differences between Amazon and frontier zone models show the spatial heterogeneity of deforestation causes even when both models analyse only the Amazon region (Table 2); these results highlight the spatiotemporal specificity of armed conflicts (and associated events) and their changing influence on deforestation.

We acknowledge that linking the periods studied to key events related to the armed conflict could expose new information about these complex relationships. For instance, this could unravel nuances about the influence of different groups' war strategies on deforestation drivers related to the armed conflict. Yet, we believe that the role of the conflict drivers identified in this study would not change drastically if the periods of the study are slightly adjusted (by 1 or 2 years), as the selected periods capture multi-year trends rather than single events.

\section{Land tenure issues associated with deforestation}

Previous research has revealed links between drug trafficking, land grabbing and deforestation in Latin America (McSweeney et al. 2014; Sesnie et al. 2017); these illegal practices have been acknowledged in Colombia (González et al. 2011; Castro-Nunez et al. 2017a; Armenteras et al. 2019; Furumo and Lambin 2020), where around 50\% of the rural lands lack clear property rights (UPRA 2014) and where illegal economies are common.

Our results provide further empirical evidence of links between land grabbing and deforestation in the Colombian Amazon, confirming results of previous research (CastroNunez et al. 2017a; Mcsweeney et al. 2017; Armenteras et al. 2019). The identified positive relationships between inequality in land ownership and deforestation support the hypotheses of forest-conflict transitions proposed by Castro-
Nunez et al. (2017a). These also go in line with recent studies, reinforcing that deforestation in the Colombian Amazon is influenced by illegal actors (e.g. drug traffickers and armed groups), unequal land distribution and land grabbing (Sánchez-Cuervo and Aide 2013b; Castro-Nunez et al. 2017a; Armenteras et al. 2019).

We did not label inequality in land ownership as a conflictrelated variable in the study, as land ownership is influenced by many other non-conflict variables, including policy. Our results show that inequality in land ownership is positively related with deforestation. At a larger extent (i.e. the Amazon area), inequality in land ownership shows a positive and significant relationship in the last two periods studied (Fig. $3 \mathrm{c}$ and d). In this case, the land ownership distribution is heterogeneous as large portions of land are state owned (forest reserves and national parks). On the other hand, a high concentration of land among few owners is observed mainly in agricultural areas predominant in the frontier zone. Deforestation hotspots are located mainly in areas where the land has few owners, while in state-owned forests, deforestation occurs mainly in easily accessible areas. Inequality in land ownership is more homogeneous across the frontier zone, making it more difficult for the model to identify links between this variable and deforestation. What is evident from the results is a positive relationship between deforestation and inequality in land ownership. Furthermore, in this case, the influence of unequal land distribution on deforestation is observed only at the Amazon scale which shows how the spatial dimension is key to expose some deforestation causes.

As robust information on land tenure and ownership is lacking and protection of forest reserves is weakly enforced in Colombia, land speculators and drug traffickers deforest for land grabbing or for covering drug trafficking activities (Mcsweeney et al. 2017; Castro-Nunez 2018; Armenteras et al. 2019). In this sense, efforts to clarify property rights (as stipulated on the peace agreement document) and to adequately regulate land use planning are key to reducing deforestation.

\section{Importance of non-conflict deforestation drivers}

The variables that best explain deforestation are elevation, precipitation, distance to towns, distance to forest boundary and distance to roads (Fig. 3). Elevation, slope and other biophysical factors usually determine the potential activities on the deforested lands, such as agriculture and urban expansion that mostly happens in the lowland as forests in the highlands have already been transformed by human activities. Furthermore, the positive, but not significant, relationship between deforestation and slope has been documented previously in montane forest, such as Andean forests (Armenteras et al. 2011), where steeper slopes are found than in our study area. 
Table 2 Changing relevance of conflict and non-conflict-related variables on deforestation over time and spatial extents

\begin{tabular}{|c|c|c|c|}
\hline & 2001-2005 & 2006-2010 & 2011-2015 \\
\hline $\begin{array}{l}\text { Significant conflict } \\
\text { variables } \\
\text { for the Amazon } \\
\text { models }\end{array}$ & dist. to landmines (-) & $\begin{array}{l}\text { dist. to conflict-related events (-) } \\
\text { inequality in land ownership (+) }\end{array}$ & $\begin{array}{l}\text { dist. to conflict-related events (-) } \\
\text { inequality in land ownership (+) }\end{array}$ \\
\hline $\begin{array}{l}\text { Significant conflict } \\
\text { variables } \\
\text { for the frontier zone } \\
\text { models }\end{array}$ & dist. to landmines (-) & $\begin{array}{l}\text { dist. to landmines (-) } \\
\text { dist. to conflict-related events (-) } \\
\text { coca density (-) }\end{array}$ & $\begin{array}{l}\text { dist. to conflict-related events (-) } \\
\text { dist. to landmines (-) }\end{array}$ \\
\hline $\begin{array}{l}\text { Possible causes of } \\
\text { differences } \\
\text { over time and spatial } \\
\text { extents }\end{array}$ & $\begin{array}{l}\text { A demilitarised zone granted to } \\
\text { FARC in } 1999 \text { is revoked in } 2002 . \\
\text { Landmines were used by armed groups } \\
\text { to isolate areas from military forces; } \\
\text { it is likely that these areas were providing } \\
\text { resources to finance } \\
\text { armed conflict activities, and as } \\
\text { consequence deforestation was } \\
\text { occurring at the same time. }\end{array}$ & $\begin{array}{l}\text { Forested areas were likely used as } \\
\text { hideouts. Conversely } \\
\text { forest boundaries where deforestation } \\
\text { occurred likely } \\
\text { became battlegrounds; and conflict } \\
\text { areas seem to be } \\
\text { far away from areas with high coca } \\
\text { densities. } \\
\text { Land grabbing becomes a major driver } \\
\text { of deforestation. }\end{array}$ & $\begin{array}{l}\text { Most armed conflict events } \\
\text { occurred in proximity to } \\
\text { deforested areas. } \\
\text { It is likely that areas previously } \\
\text { deforested and in proximity } \\
\text { to forests continue as } \\
\text { battlegrounds. This seems to } \\
\text { benefit land grabbing and } \\
\text { deforestation. }\end{array}$ \\
\hline $\begin{array}{l}\text { Significant non-conflict } \\
\text { variables } \\
\text { for the Amazon } \\
\text { models }\end{array}$ & $\begin{array}{l}\text { elevation (-) } \\
\text { precipitation (-) } \\
\text { dist. to settlements (-) } \\
\text { protected areas (-) }\end{array}$ & $\begin{array}{l}\text { dist. to forest } \\
\text { boundary (-) } \\
\text { elevation (-) } \\
\text { dist. to settlements }(-) \\
\text { dist. to roads (-) } \\
\text { precipitation (-) }\end{array}$ & $\begin{array}{l}\text { dist. to roads (-) } \\
\text { dist. to forest } \\
\text { boundary (-) } \\
\text { elevation (-) } \\
\text { dist. to settlements (-) }\end{array}$ \\
\hline $\begin{array}{l}\text { Significant non-conflict } \\
\text { variables } \\
\text { for the frontier zone } \\
\text { models }\end{array}$ & $\begin{array}{l}\text { elevation (-) } \\
\text { dist. to forest boundary (-) } \\
\text { dist. to roads (-) } \\
\text { dist. To settlements (-) }\end{array}$ & $\begin{array}{l}\text { dist. to roads }(-) \\
\text { dist. to forest } \\
\text { boundary }(-) \\
\text { elevation }(-)\end{array}$ & $\begin{array}{l}\text { dist. to forest } \\
\text { boundary (-) } \\
\text { dist. to roads (-) } \\
\text { elevation (-) }\end{array}$ \\
\hline $\begin{array}{l}\text { Possible causes of } \\
\text { differences } \\
\text { over time and spatial } \\
\text { extents }\end{array}$ & \multicolumn{3}{|c|}{$\begin{array}{l}\text { Biophysical and forest accessibility variables are significant over time and spatial extents. Distance to settlements loses } \\
\text { relevance as deforestation occurs farther from settlements. The effect of precipitation is only captured at large scale in the } \\
\text { Amazon model. }\end{array}$} \\
\hline
\end{tabular}

The sign in parentheses indicate the statistical relationship. For distance variables, the relationship is counterintuitive

Precipitation data have been previously studied in relation to deforestation as most of deforestation occurs during dry season (Armenteras et al. 2013a). This research did not analyse inter-annual/seasonal variation. In the same manner, the resolution of the precipitation dataset limited the capacity of the model to associate the precipitation with the deforestation. Hence, we conclude that precipitation data might be relevant to analyse seasonal deforestation as well as to evaluate deforestation at department or national level but not at the local level.

Since wood and livestock trade usually takes place in cities, accessibility variables such as distance to towns and roads play an important role in explaining deforestation. In logging areas, roads are built to access the forest (Barber et al. 2014). Moreover, infrastructure development to connect communities increases land value and access to forest and markets, making commercial activities on these lands more profitable (Nepstad et al. 2001; Etter et al. 2006b; Dávalos et al. 2011, 2014). Although the influence of roads and rivers on deforestation is typically believed to happen only a few kilometres away from roads (Barber et al. 2014), deforestation in the studied area is observed even farther than $200 \mathrm{~km}$ from roads and rivers. In the same way, as shown by our results, distance to the outer forest boundary is important because deforestation usually takes place in proximity to the external boundaries of the forests; as described in other studies, deforestation in the Colombian Amazon usually occurs on a north (outer boundary) to south-east direction (Etter et al. 2006b; Carr 2009).

Surprisingly, population density did not play a significant role in explaining deforestation in our models, which may be a consequence of rural-urban migration trends observed throughout Latin America (Grau and Aide 2008). While some studies have mentioned the opposite (Geist and Lambin 2001), others have shown that demographic factors do not explain vegetation change at broader scales (Grau and Aide 2008; Sánchez-Cuervo et al. 2012; Sánchez-Cuervo and Aide 2013a; Leisher et al. 2013). Moreover, studies have linked forest clearing and pasture establishment as means for land grabbing, actions that might be led by specific groups rather than by migrating or growing population (Dávalos et al. 2014; 
Hoffmann et al. 2018). The former, coupled with the reduced temporal dimension in our population dataset, contributes to explain the weak relationship found between population density and deforestation.

\section{Deforestation risks in the Colombian Amazon}

For the Amazon-scale model, deforestation risk increases in spatial extent over time, while the intensity of the risk does not follow the same pattern, being high in the first and last periods (Fig. 4), these coincide with the observed deforestation on each period (Fig. 2). Higher deforestation risks are observed in lowlands, in proximity to roads and towns, which confirms findings of previous research (Geist and Lambin 2001; Rosa et al. 2013; Armenteras et al. 2013a; Dávalos et al. 2014; Salonen et al. 2014; Murad and Pearse 2018; Negret et al. 2019). Incremental changes in deforestation risks between 2001 and 2010 are observed in zones in proximity to limits of protected areas and forest reserves.

In the frontier zone, deforestation risk patterns are similar across time periods. This could be explained by the relatively consistent spatial occurrence of deforestation in the three periods studied. As mentioned above, deforestation in this area occurs following the specific spatial patterns of the rather unchanging road network, the forest edge and elevation, rather than the more dynamic conflict-related variables. However, the intensity of deforestation risk changes spatially, expanding in the southern and northern areas of the frontier zone, but reducing in the east; the central area presents high risk in all the periods. These changes in intensity usually take place in areas close to previously deforested patches, urban settlements and roads.

As part of the 2016 peace agreement between the government and FARC, an effort to encourage displaced people to return to their home land is likely to cause rapid changes in land cover, especially in areas of difficult accessibility during the armed conflict (Baptiste et al. 2017; Negret et al. 2017). Therefore, information provided by the risk maps presented in this study becomes important in guiding conservation planning efforts and in anticipating the possible effects of unsustainable use of forest resources in areas where communities may be directly depending on them after the conflict period, as well as areas where companies intend to establish large-scale agribusiness (Stevens et al. 2011; Castro-Nunez et al. 2016). Peacebuilding efforts are considered vital to achieve sustainable development and forest conservation in areas emerging from armed conflict (Castro-Nunez 2018). Addressing the causes of armed conflict by facilitating the access of rural population to public services; infrastructure; adequate access to land titling, together with sustainable land use practices, and involving different stakeholders including the food supply chain could potentially contribute to tackling deforestation more effectively (Arroyo 2016; Castro-Nunez et al. 2017b, 2020; Furumo and Lambin 2020).

Despite that the net zero deforestation target proposed for Colombia in the 2015 United Nations Climate Change Conference was not met, Colombia has shown progress in reducing deforestation (Furumo and Lambin 2020), and the governments of Norway, UK and Germany recently renewed their cooperation agreements with the Colombian government along with additional funds to achieve the reduced deforestation goals. Based on the results of this study, we highlight actions that could maximise the impacts of cooperation funds. First, prioritisation of areas under high risk of deforestation for land titling programs aiming to reduce new claims on deforested lands and the recuperation of illegally occupied lands. Second, improving and updating of the rural cadastre, as this can help to detect land grabbing, and land market speculation with deforested lands. Third, adequate funding for protected areas, which means better monitoring and effective law enforcement against groups causing deforestation. Although the implementation of a multipurpose rural cadastre and an extensive land titling scheme are underway (UPRA 2017; ANT 2020), areas at risk of deforestation are not prioritised. On the other hand, efforts to achieve long-term financing of protected areas are in motion, and an example of this is the initiative Heritage Colombia, which brings together public and private actors to close the financing gaps of protected areas, although the project is not operational yet, important advances in financing requirements and mechanisms are in progress (Minambiente 2017; The World Bank 2020).

To improve the actual understanding of the role of conflict in the deforestation process, it becomes necessary to acquire up to date and more spatially explicit information about population movement, disaggregated data of civil victims associated with the conflict, land tenure, cattle population and cocaplanted areas. Recent press and institutional reports (Hettler et al. 2018; IDEAM 2018; Revista, 2019) have shown alarming increases in deforestation rates after the peace agreement, which might be associated with poor institutional presence and response capacity. Robust, timely data, such as near real-time deforestation alerts (Reymondin et al. 2012; Hansen et al. 2016) combined with institutional efforts to enforce forest protection, could yield better results in the battle against deforestation.

\section{Conclusions}

The modelling approach presented in this study aims to identify the changing role of armed conflict in the deforestation process in the Colombian Amazon. Our findings indicate that armed conflict-related drivers are dynamic over time and space, and so is their influence on deforestation. Firstly, we 
identified changing role of conflict over time. Secondly, this empirical study shows that a deforestation model for the entire Amazon region is not the same for the more dynamic frontier zone. Different key drivers are in place. We also confirm that conflict is not the main determinant of deforestation: variables with the most influence are the ones related with access to forests. The positive relationships found between deforestation and unequal distribution of land provide further evidence to recent findings that identify land grabbing as a key deforestation driver. Irrespective of the period studied and the intensity of conflict, the deforestation risks follow a wave pattern that has been previously documented. As the data used in the study cover periods of conflict and the beginnings of the peace negotiations, when the armed actions reduced progressively, the findings might be used as a baseline to compare deforestation drivers under conflict and decreased armed conflict scenarios.

Supplementary Information The online version contains supplementary material available at https://doi.org/10.1007/s10113-021-01770-6.

Acknowledgements We acknowledge the University of Twente for the UT-ITC excellence scholarship awarded To O. Bautista-Céspedes that partly founded this research. Thanks to A. Nowak, A. Coca-Castro, H. Kloosterman, J. Morales, A. Shahpurwala, the editor and two anonymous reviewers for their constructive comments. This research contributes to the project 18_III_106_COL_A_Sustainable productive strategies funded by the International Climate Initiative (IKI).

Open Access This article is licensed under a Creative Commons Attribution 4.0 International License, which permits use, sharing, adaptation, distribution and reproduction in any medium or format, as long as you give appropriate credit to the original author(s) and the source, provide a link to the Creative Commons licence, and indicate if changes were made. The images or other third party material in this article are included in the article's Creative Commons licence, unless indicated otherwise in a credit line to the material. If material is not included in the article's Creative Commons licence and your intended use is not permitted by statutory regulation or exceeds the permitted use, you will need to obtain permission directly from the copyright holder. To view a copy of this licence, visit http://creativecommons.org/licenses/by/4.0/.

\section{References}

AICMA (2017) Víctimas de Minas Antipersonal. http://www. accioncontraminas.gov.co/estadisticas/Paginas/victimas-minasantipersonal.aspx. Accessed 8 Dec 2017

Álvarez MD (2003) Forests in the Time of Violence. J Sustain For 16:4768. https://doi.org/10.1300/J091v16n03 03

Alvarez-Berríos NL, Mitchell Aide T (2015) Global demand for gold is another threat for tropical forests. Environ Res Lett 10:029501. https://doi.org/10.1088/1748-9326/10/2/029501

ANT (2020) Informe de gestión de la Agencia Nacional de Tierras 2019. Bogotá D.C, Colombia

Arcila OH (2010) La Amazonia colombiana urbanizada un análisis de sus asentamientos humanos. Instituto Amazónico de Investigaciones Científicas-Sinchi, Bogotá D.C
Armenteras D, Rudas G, Rodriguez N (2006) Patterns and causes of deforestation in the Colombian Amazon. Ecol Indic 6:353-368. https://doi.org/10.1016/j.ecolind.2005.03.014

Armenteras D, Rodríguez N, Retana J, Morales M (2011) Understanding deforestation in montane and lowland forests of the Colombian Andes. Reg Environ Chang 11:693-705. https://doi.org/10.1007/ s10113-010-0200-y

Armenteras D, Cabrera E, Rodríguez N, Retana J (2013a) National and regional determinants of tropical deforestation in Colombia. Reg Environ Chang 13:1181-1193. https://doi.org/10.1007/s10113-0130433-7

Armenteras D, Rodríguez N, Retana J (2013b) Landscape dynamics in Northwestern Amazonia: an assessment of pastures, fire and illicit crops as drivers of tropical deforestation. PLoS One 8:e54310. https://doi.org/10.1371/journal.pone.0054310

Armenteras D, Negret P, Melgarejo LF, Lakes TM, Londoño MC, et al (2019) Curb land grabbing to save the Amazon. Nat Ecol Evol 3: 1497. https://doi.org/10.1038/s41559-019-1020-1

Arroyo P (2016) Land rights and conservation issue brief 2016: land rights, conservation, and peace in the Colombian Amazon. Bogota

Baptiste B, Pinedo-Vasquez M, Gutierrez-Velez VH, Andrade GI, Vieira $P$, et al (2017) Greening peace in Colombia. Nat Ecol Evol 1:0102. https://doi.org/10.1038/s41559-017-0102

Barber CP, Cochrane MA, Souza CM, Laurance WF (2014) Roads, deforestation, and the mitigating effect of protected areas in the Amazon. Biol Conserv 177:203-209. https://doi.org/10.1016/j. biocon.2014.07.004

Baumann M, Kuemmerle T (2016) The impacts of warfare and armed conflict on land systems. J Land Use Sci 11:672-688. https://doi. org/10.1080/1747423X.2016.1241317

Bivand R (2017) OGR shapefile encoding. https://cran.r-project.org/web/ packages/rgdal/vignettes/OGR_shape_encoding.pdf. Accessed 8 Dec 2017

Bonilla Mejía L (2020) Mining and human capital accumulation: Evidence from the Colombian gold rush. J Dev Econ 145:102471. https://doi.org/10.1016/j.jdeveco.2020.102471

Bradley A (1997) The use of the area under the ROC curve in the evaluation of machine learning algorithms. Pattern Recognit 30:11451159. https://doi.org/10.1016/S0031-3203(96)00142-2

Cardona L, Jimenez J, Vanegas N (2014) Landmine detection technologies to face the deminig problem in Antioquia. Dyna 81:115-1. https://doi.org/10.15446/dyna.v81n183.37441

Carr D (2009) Rural migration: The driving force behind tropical deforestation on the settlement frontier. Prog Hum Geogr 33:355-378. https://doi.org/10.1177/0309132508096031

Castro-Nunez A (2018) Responding to climate change in tropical countries emerging from armed conflicts: harnessing climate finance, peacebuilding, and sustainable food. Forests 9:621. https://doi.org/ $10.3390 /$ f 9100621

Castro-Nunez A, Mertz O, Quintero M (2016) Propensity of farmers to conserve forest within REDD+ projects in areas affected by armedconflict. For Policy Econ 66:22-30. https://doi.org/10.1016/j.forpol. 2016.02.005

Castro-Nunez A, Mertz O, Buritica A, Sosa CC, Lee ST (2017a) Land related grievances shape tropical forest-cover in areas affected by armed-conflict. Appl Geogr 85:39-50. https://doi.org/10.1016/j. apgeog.2017.05.007

Castro-Nunez A, Mertz O, Sosa CC (2017b) Geographic overlaps between priority areas for forest carbon-storage efforts and those for delivering peacebuilding programs: implications for policy design. Environ Res Lett 12:054014. https://doi.org/10.1088/1748-9326/ aa6f20

Castro-Nunez A, Charry A, Castro-Llanos F, Sylvester J, Bax V (2020) Reducing deforestation through value chain interventions in countries emerging from conflict: The case of the Colombian cocoa 
sector. Appl Geogr 123:102280. https://doi.org/10.1016/j.apgeog. 2020.102280

Centro Nacional de Memoria Histórica y Observatorio de Memoria y Conflicto (2018) Observatorio de Memoria y conflicto. http:// centrodememoriahistorica.gov.co/observatorio/. Accessed 4 Sep 2019

Chadid MA, Dávalos LM, Molina J, Armenteras D (2015) A Bayesian spatial model highlights distinct dynamics in deforestation from coca and pastures in an Andean biodiversity hotspot. Forests 6:3828-3846. https://doi.org/10.3390/f6113828

Contributors OpenStreetMaps (2017) OpenStreetMaps. https://planet. osm.org

DANE (2015) Geoportal DANE - Consulta colaborativa de centros poblados y veredas (beta). https://geoportal.dane.gov.co/v2/index. php?page=elementoConsultaDivipola. Accessed 8 Dec 2017

Dávalos LM, Bejarano AC, Hall MA, Correa HL, Corthals A, et al (2011) Forests and drugs: coca-driven deforestation in tropical biodiversity hotspots. Environ Sci Technol Sci Technol 45:1219-1227. https:// doi.org/10.1021/es102373d

Dávalos LM, Holmes JS, Rodríguez N, Armenteras D (2014) Demand for beef is unrelated to pasture expansion in northwestern Amazonia. Biol Conserv 170:64-73. https://doi.org/10.1016/j.biocon.2013.12. 018

Dávalos LM, Sánchez KM, Armenteras D (2016) Deforestation and coca cultivation rooted in twentieth-century development projects. Forum Biosci Biosci 974:974-982. https://doi.org/10.1093/biosci/biw118

DESA (2016) The sustainable development goals report 2016, 2nd edn. United Nations, New York

Duque-Lazo J, Van Gils H, Groen TA, Navarro-Cerrillo RM (2016) Transferability of species distribution models: The case of Phytophthora cinnamomi in Southwest Spain and Southwest Australia. Ecol Model 320:62-70. https://doi.org/10.1016/j. ecolmodel.2015.09.019

Eden M (1990) Amazonia, ecology and land management in. Belhaven Press, London

Efron B (1979) bootstrap methods: another look at the Jackknife. Ann Stat 7:1-26. https://doi.org/10.1214/aos/1176344552

Etter A, Mcalpine C, Phinn S, Pullar D, Possingham H (2006a) Unplanned land clearing of Colombian rainforests: Spreading like disease? Landsc Urban Plan 77:240-254. https://doi.org/10.1016/j. landurbplan.2005.03.002

Etter A, McAlpine C, Wilson K, Phinn S, Possingham H (2006b) Regional patterns of agricultural land use and deforestation in Colombia. Agric Ecosyst Environ 114:369-386. https://doi.org/10. 1016/j.agee.2005.11.013

FAO (2016) The global forest resources assessment 2015, 2nd edn. Food and Agriculture Organization of The United Nations, Rome

Farrar DE, Glauber RR (1967) Multicollinearity in regression analysis: the problem revisited. Source Rev Econ Stat 49:92-107. https://doi. org/10.2307/1937887

Fawcett T (2005) An introduction to ROC analysis. Pattern Recogn Lett 27:861-874. https://doi.org/10.1016/j.patrec.2005.10.010

Fergusson L, Romero D, Vargas JF (2014) The environmental impact of civil conflict: the deforestation effect of paramilitary expansion in colombia the deforestation.

Fick SE, Hijmans RJ (2017) WorldClim 2: new 1-km spatial resolution climate surfaces for global land areas. Int J Climatol Int J Clim 37: 4302-4315. https://doi.org/10.1002/joc.5086

Finer M, Mamani N (2020) MAAP \#120: Deforestation in the Colombian Amazon - 2020 | MAAP. https://maaproject.org/2020/colombian amaz/. Accessed 25 Jul 2020

Freeman EA, Moisen G (2008) PresenceAbsence: An R Package for Presence Absence Analysis. J Stat Softw 23:1-31. https://doi.org/ 10.18637/jss.v023.i11

Furumo PR, Lambin EF (2020) Scaling up zero-deforestation initiatives through public-private partnerships: a look inside post-conflict
Colombia. Glob Environ Chang 62:102055. https://doi.org/10. 1016/j.gloenvcha.2020.102055

Geist HJ, Lambin EF (2001) What drives tropical deforestation? Neuve, Louvain la

González J, Etter AA, Sarmiento AH, Orrego SA, Ramírez C, et al (2011) Análisis de tendencias y patrones espaciales de deforestación en Colombia. Instituto de Hidrología, Meteorología y Estudios Ambientales-IDEAM, Bogotá D.C., Colombia

Grau HR, Aide M (2008) Globalization and land-use transitions in Latin America. Ecol Soc 13:16. https://doi.org/10.5751/ES-02559130216

Hansen MC, Krylov A, Tyukavina A, Potapov P V, Turubanova S, et al (2016) Humid tropical forest disturbance alerts using Landsat data. Environ Res Lett 11:034008. https://doi.org/10.1088/1748-9326/11/ 3/034008

Hansen MC, Potapov PV, Moore R, Hancher M, Turubanova SA, et al (2013) High-resolution global maps of 21 st-century forest cover change. Science (80-) 342:850-853. https://doi.org/10.1126/ science. 1244693

Hanson T, Brooks TM, Da Fonseca GABB, Hoffmann M, Lamoreux JF, et al (2009) Warfare in biodiversity hotspots. Conserv Biol 23:578 587. https://doi.org/10.1111/j.1523-1739.2009.01166.x

Hettler B, Thieme A, Finer M (2018) MAAP \#97: Deforestation Surge in the Colombian Amazon, 2018 update | MAAP. Maap Proj, In https://maaproject.org/2019/colombia-2018-4/.

Hijmans RJ (2016) Introduction to the 'raster' package (version 2. 5-8). 1 27

Hoffmann C, García Márquez JR, Krueger T (2018) A local perspective on drivers and measures to slow deforestation in the AndeanAmazonian foothills of Colombia. Land use policy 77:379-391. https://doi.org/10.1016/j.landusepol.2018.04.043

Holzman BA (2008) Tropical forest biomes. Greenwood Press, Westport

Ibañez AM, Vélez CE (2007) Civil conflict and forced migration: the micro determinants and welfare losses of displacement in Colombia. World Dev 36:659-676. https://doi.org/10.1016/j. worlddev.2007.04.013

IDEAM (2018) Boletín de detección temprana de deforestación 17 Cuarto trimestre 2018. Bogotá D.C, Colombia

Idrobo N, Mejía D, Tribin AM (2014) Illegal Gold Mining and Violence in Colombia. Peace Econ Peace Sci Public Policy 20:83-111. https://doi.org/10.1515/peps-2013-0053

IGAC (2012) Atlas de la Distribución de la Propiedad Rural en Colombia. Instituto Geográfico Agustín Codazzi, Bogotá D.C

Jou Y-J, Chien-Chia, Huang L, Cho H-J, Jou Y-J, et al (2014) A VIFbased optimization model to alleviate collinearity problems in multiple linear regression. Comput Stat 29:1515-1541. https://doi.org/ 10.1007/s00180-014-0504-3

Landholm DM, Pradhan P, Kropp JP (2019) Diverging forest land use dynamics induced by armed conflict across the tropics. Glob Environ Chang 56:86-94. https://doi.org/10.1016/j.gloenvcha. 2019.03.006

Laurance WF, Albernaz AKM, Schroth G, Fearnside PM, Bergen S, et al (2002) Predictors of deforestation in the Brazilian Amazon. J Biogeogr 29:737-748. https://doi.org/10.1046/j.1365-2699.2002. 00721.x

Leblois A, Damette O, Wolfersberger J (2017) What has Driven Deforestation in Developing Countries Since the 2000s? Evidence from New Remote-Sensing Data. World Dev 92:82-102. https://doi. org/10.1016/j.worlddev.2016.11.012

Leisher C, Touval J, Hess S, Boucher T, Reymondin L (2013) Land and forest degradation inside protected areas in Latin America. Diversity 5:779-795. https://doi.org/10.3390/d5040779

Lloyd CT, Sorichetta A, Tatem AJ (2017) High resolution global gridded data for use in population studies. Sci DATA. https://doi.org/10. 1038/sdata.2017.1 
MAAP (2019) MAAP \#101: Deforestation Continues in Colombian Amazon (2019) | MAAP. https://maaproject.org/2019/ chiribiquete 2019/.

Makki I, Younes R, Francis C, Bianchi T, Zucchetti M (2017) A survey of landmine detection using hyperspectral imaging. ISPRS J Photogramm Remote Sens 124:40-53. https://doi.org/10.1016/j. isprsjprs.2016.12.009

Malhi Y, Roberts T, Betts RA, Killeen TJ, Li W, et al (2007) Climate change, deforestation, and the fate of the Amazon. Scienceexpress. https://doi.org/10.1126/science.1146961

McSweeney K, Nielsen EA, Taylor MJ, Wrathall DJ, Pearson Z, et al (2014) Drug Policy as Conservation Policy: Narco-Deforestation. Science (80-) 343:489-490. https://doi.org/10.1126/science. 1244082

Mcsweeney K, Richani N, Pearson Z, Devine J, Wrathall DJ (2017) Why Do Narcos Invest in Rural Land? J Lat Am Geogr 16:3-29. https:// doi.org/10.1353/lag.2017.0019

Minambiente (2017) Nace Herencia Colombia: el programa para proteger nuestro capital natural para siempre. Nace Herencia Colomb. el programa para Prot. nuestro Cap. Nat. para siempre, In https:// www.minambiente.gov.co/index.php/noticias-minambiente/3454nace-herencia-colombia-el-programa-para-proteger-nuestro-capitalnatural-para-siempre

Miranda J, Börner J, Kalkhul M, Soares-Filho BS (2019) Land speculation and conservation policy leakage in Brazil Recent citations What Drives the Erasure of Protected Areas? Evidence from across the Brazilian Amazon Derya Keles et al. Environ Res Lett 14:1-11. https://doi.org/10.1088/1748-9326/ab003a

Morales L (2017) Peace and environmental protection in Colombia: proposals for sustainable rural development

Müller H, Griffiths P, Hostert P (2016) Long-term deforestation dynamics in the Brazilian Amazon-Uncovering historic frontier development along the Cuiabá-Santarém highway. Int J Appl Earth Obs Geoinf 44:61-69. https://doi.org/10.1016/J.JAG.2015.07.005

Murad CA, Pearse J (2018) Landsat study of deforestation in the Amazon region of Colombia: Departments of Caquetá and Putumayo. Remote Sens Appl Soc Environ 11:161-171. https://doi.org/10. 1016/j.rsase.2018.07.003

Murillo-Sandoval PJ, Van Dexter K, Van Den Hoek J, Wrathall D, Kennedy R (2020) The end of gunpoint conservation: forest disturbance after the Colombian peace agreement. Environ Res Lett 15: 034033. https://doi.org/10.1088/1748-9326/ab6ae3

Negret PJ, Allan J, Braczkowski A, Maron M, Watson JEM (2017) Need for conservation planning in postconflict Colombia. Conserv Biol 31:499-500. https://doi.org/10.1111/cobi.12935

Negret PJ, Sonter L, Watson JEM, Possingham HP, Jones KR, et al (2019) Emerging evidence that armed conflict and coca cultivation influence deforestation patterns. Biol Conserv 239:108176. https:// doi.org/10.1016/j.biocon.2019.07.021

Nepstad D, Carvalho G, Cristina Barros A, Alencar A, Paulo Capobianco $\mathrm{J}$, et al (2001) Road paving, fire regime feedbacks, and the future of Amazon forests. For Ecol Manage 154:395-407. https://doi.org/10. 1016/S0378-1127(01)00511-4

ODC (2017) SIDCO: Cultivos Ilícitos por municipio. Obs. Drog. Colomb. http://www.odc.gov.co/sidco/oferta/cultivos-ilicitos/ departamento-municipio.

RAISG (2012) Amazonia under pressure. https://www. amazoniasocioambiental.org/wp-content/uploads/2017/01/ Amazonia bajo_presion.pdf.

Revista S (2019) Sigue en aumento la deforestación en Colombia. Rev Sem. https://sostenibilidad.semana.com/impacto/articulo/sigue-enaumento-la-deforestacion-en-colombia/43319.

Reymondin L, Jarvis A, Perez-Uribe A, Touval J, Argote K, et al (2012) A methodology for near real-time monitoring of habitat change at continental scales using MODIS-NDVI and TRMM. http://www.
terra-i.org/dam/jcr:508a0e27-3c91-4022-93dd-81cf3fe31f42/TerraiMethod.pdf.

Rincón-Ruiz A, Pascual U, Flantua S (2013) Examining spatially varying relationships between coca crops and associated factors in Colombia, using geographically weight regression. Appl Geogr 37:23-33. https://doi.org/10.1016/j.apgeog.2012.10.009

Rocha AD, Groen TA, Skidmore AK, Darvishzadeh R, Willemen L (2017) The Naïve Overfitting Index Selection (NOIS): A new method to optimize model complexity for hyperspectral data. ISPRS J Photogramm Remote Sens 133:61-74. https://doi.org/10.1016/j. isprsiprs.2017.09.012

Rosa I, Purves D, Souza C, Ewers R (2013) Predictive modelling of contagious deforestation in the Brazilian Amazon. PLoS One 8: e77231. https://doi.org/10.1371/journal.pone.0077231

Ruiz AR, Pascual U, Romero M (2013) An exploratory spatial analysis of illegal coca cultivation in Colombia using local indicators of spatial association and socioecological variables. Ecol Indic 34:103-112. https://doi.org/10.1016/j.ecolind.2013.04.008

Salonen M, Maeda EE, Toivonen T (2014) Evaluating the impact of distance measures on deforestation simulations in the fluvial landscapes of Amazonia. Ambio 43:779-790. https://doi.org/10.1007/ s13280-013-0463-x

Sánchez-Cuervo AM, Aide TM (2013a) Consequences of the armed conflict, forced human displacement, and land abandonment on forest cover change in Colombia: a multi-scaled analysis. Ecosystems 16: 1052-1070. https://doi.org/10.1007/s10021-013-9667-y

Sánchez-Cuervo AM, Aide TM (2013b) Identifying hotspots of deforestation and reforestation in Colombia (2001-2010): implications for protected areas. Ecosphere 4:1-21. https://doi.org/10.1890/ES1300207.1

Sánchez-Cuervo AM, Aide TM, Clark ML, Etter A (2012) Land cover change in Colombia: Surprising forest recovery trends between 2001 and 2010. PLoS One 7:e43943. https://doi.org/10.1371/ journal.pone. 0043943

Santé I, García AM, Miranda D, Crecente R (2010) Cellular automata models for the simulation of real-world urban processes: A review and analysis. Landsc Urban Plan 96:108-122. https://doi.org/10. 1016/j.landurbplan.2010.03.001

Schultz C, Alegría AC, Cornelis J, Sahli H (2016) Comparison of spatial and aspatial logistic regression models for landmine risk mapping. Appl Geogr 66:52-63. https://doi.org/10.1016/j.apgeog.2015.11. 005

Sesnie SE, Tellman B, Wrathall D, McSweeney K, Nielsen E, et al (2017) A spatio-temporal analysis of forest loss related to cocaine trafficking in Central America. Environ Res Lett 12:054015. https://doi.org/ 10.1088/1748-9326/aa6fff

SIAC (2020) Geo-visor sistema de información ambiental de Colombia. In: Sist. Inf. Ambient. Colomb. http://sig.anla.gov.co:8083/. Accessed 25 Jul 2020

SIAC S de IA de C (2017) Catálogo de mapas Catálogo de mapas. http:// www.siac.gov.co/catalogo-de-mapas. Accessed 22 Jul 2017

Stevens K, Campbell L, Urquhart G, Kramer D, Qi J (2011) Examining complexities of forest cover change during armed conflict on Nicaragua's Atlantic Coast. Biodivers Conserv 20:2597-2613. https://doi.org/10.1007/s10531-011-0093-1

The World Bank (2020) Forest conservation and sustainability in the heart of the Colombian Amazon (P144271) implementation. Bogotá D.C, Colombia

UCDP (2016) UCDP - Uppsala Conflict Data Program. http://ucdp.uu. se/\#country/100.

UNODC (2017) Monitoreo de territorios afectados por cultivos ilicitos 2016. Bogotá D.C, Colombia

UPRA (2014) Bases conceptuales procesos de regularización de la propiedad rural y acceso a tierras. Imprenta Nacional, Bogotá D.C., Colombia 
UPRA (2017) Lineamientos y criterios técnicos para la focalización territorial de la política pública de ordenamiento social de la propiedad rural. Bogotá D.C, Colombia

USGS (2015) Shuttle Radar Topography Mission (SRTM) 1 Arc-Second Global | The Long Term Archive. https://lta.cr.usgs.gov/ SRTM1Arc.

Van Soesbergen AJJ, Mulligan M (2014) Modelling multiple threats to water security in the Peruvian Amazon using the WaterWorld policy support system. Earth Syst Dyn 5:55-65. https://doi.org/10.5194/ esd-5-55-2014
Zuur AF, Ieno EN, Elphick CS (2010) A protocol for data exploration to avoid common statistical problems. Methods Ecol Evol 1:3-14. https://doi.org/10.1111/j.2041-210X.2009.00001.x

Publisher's note Springer Nature remains neutral with regard to jurisdictional claims in published maps and institutional affiliations. 